\title{
The Voice of the Stone of Destiny : an Enquiry into the Choice of Kings by Augury
}

\section{E. Sidney Hartland F.S.A.}

To cite this article: E. Sidney Hartland F.S.A. (1903) The Voice of the Stone of Destiny : an Enquiry into the Choice of Kings by Augury, Folklore, 14:1, 28-60, DOI: 10.1080/0015587X.1903.9719334

To link to this article: http://dx.doi.org/10.1080/0015587X.1903.9719334

曲 Published online: 06 Feb 2012.

Submit your article to this journal $[\pi$

Џll Article views: 1 


\section{THE VOICE OF THE STONE OF DESTINY :}

AN Enquiry into the Cholce of Kings by Augury.

BY R. SIDNEY HARTLAND, F.S.A,

(Read at the Meeting of 12th November, 1902.)

THE famous Coronation Stone has an authentic history of six hundred years. At the time of the conquest of Scotland by Edward I., it was the stone on which the kings of the Scots were, according to immemorial custom, installed. Regarded by the Scots as sacred, it was therefore removed by Edward's order from Scone, where it stood, to Westminster, and was inclosed in what is now, and has been ever since, the Coronation Chair. Its earlier history, as distinguished from conjecture and legend, goes no farther back than the middle of the thirteenth century, or something less than half a century before its removal to Westminster, when it is recorded by Fordun that Alexander III. was solemnly placed upon it and hallowed to king by the Bishop of St. Andrews (1249). But what is wanting in authentic history has been abundantly made up in legend. The tale, of which there are two versions, is the creation of a literary age. The Irish version brings it, with the Tuatha De Danann, from Lochlann, or Scandinavia, to Ireland. The Scottish version traces it on the other hand from Egypt, whence it was carried by the Milesians. This was improved upon, to the extent of identifying the stone with that used by Jacob as a pillow on his journey from Beersheba to Haran. The attempt was thus made, by connecting the ruling race in Scotland with the legends of the Hebrew patriarchs, to confer upon the stone the united sanctity of religion, of antiquity, and of patriotism.

In the course of its wanderings the stone is said to have reached Tara: and it is declared to be the famous Lia Fril, 
or Stone of Destiny, one of the two wonders of Tara celebrated in Irish sagas. We are indebted to the Book of Lismore, a fifteenth-century manuscript, for an enumeration of the wonderful properties of the Lia Fail. The Colloquy with the Ancients, which is comprised in this precious manuscript, records a number of Irish traditions, some of which would else in all probability have perished beyond recovery. There we learn-the account is put into the mouth of no less a personage than Ossian himself-that "Any one of all Ireland on whom an ex parte imputation rested was set upon that stone: then if the truth were in him be would turn pink and white; but if otherwise, it was a black spot that in some conspicuous place would appear on him. Farther, when Ireland's monarch stepped on to it the stone would cry out under him, and her three archwaves would boom in answer: as the wave of Cleena, the wave of Ballintoy, and the wave of Loch Rury; when a provincial king went on to it the flag would rumble under him; when a barren woman trod on it, it was a dew of dusky blood that broke out on it; when one that would bear children tried it, it was a 'nursing drop' "-that is, says Mr. Standish O'Grady, from whose translation I quote, semblance of milk-"that it sweated." I The Colloquy is imperfect, the legible portion of the manuscript ceasing a line or two further on, just as we are about to be told how it was that the stone left Ireland." Its subsequent adventures are related by Keating, who says that it was sent to Feargus the Great, "to sit upon, for the purpose of being proclaimed king of Scotland." However, it is not to the adventures of the stone, but to its properties that I wish now to direct attention. With regard to the former, all that I need add is that the legend has been subjected by

\footnotetext{
p. 264 .

'Standish If. O'Grady, Silva Cadulica (two vols, London, 1892), vol. ii.,

- There are other manuscripts of the Colloginy, but none of them contain the seryel of the adventures of the Lia Fail. See the preface to Stoke's Edition, Jrische Texts, 4th ser. (Leipaig, 1900).
} 
Skene, and more recently by Mr. P. J. O'Reilly, to an exhaustive analysis, which renders it clear that there is no trustworthy evidence that the stone of Tara is the Coronation Stone. The antecedent improbability is great; and even if it were indisputable that the stone in question was no longer at Tara in the eleventh century, the chasm between that period and Fergus, whose very existence only rests on legend, would still have to be bridged, and the variants of the story would need to be reconciled. ${ }^{1}$

The properties of the stone of Tara were oracular; and the stone itself was one of a large class of stones endowed in popular opinion with divining powers, and actually resorted to for the purpose of inquiry. When the reputation of an oracle is once established, it is consulted for many purposes. Not only political, but juridical and domestic purposes are enumerated by the author of the Colloquy in regard to the Lia Fail. Among these functions is the recognition of the monarch. The phrase used in the Colloquy is ambiguous. It is not stated why, or on what occasion, the stone was expected to make its voice heard. In practice the only object of obtaining such a recognition would be that of determining the succession to the throne. Keating supplies the missing explanation. "It was a stone," he says, "on which were enchantments, for it used to roar under the person who had the best right to obtain the sovereignty of Ireland at the time of the men of Ireland being in assembly at Tara to choose a king over them."

' Skene's paper is in the l'roceedings of the Sacioty of Antiquarios of Scotland, vol, viii., p. 68 ; Mr. O'Reilly's in The Journal of the Royal Society of Amiguaries of Irelamd, vil. xxxii., p. 77. The stone now called the Lia Fiail at Tara is clearly not the stone of tradition.

- Keating, The Ifistory of Ireland (edited and transtaled by David Comyn, London, I902), vol. i., p. rol. See also pp. 207, 209 On the latter page "a prem from a certain book of invasion "is quoted at length. It contains an enumeration of the four jewels of the Tuatha De Daranu, among thent the Lia Fail, "which used to roar under the king of Ireland." In the Baile all Scall (The Champion's Ecstasy) Conna of the IIundred Fights steps on the stone accidentally, and is told by the druid who accompanies him, "Fal has 


\section{The Voice of the Stone of Destiny.}

Whether as a matter of fact the stone ever was consulted with this object is another question. It is enough at present to know that Irish tradition asserted this use of the oracle. In a semi-civilised community a disputed succession is of frequent occurrence. To prevent a dispute, and to settle it when it arises, various means are adopted. The usual Irish plan seems to have been the custom of Tanistry. "During the lifetime of a chief," Sullivan tells us, "his successor was elected under the name of Tanaiste; and on the death of the former the latter succeeded him. The Tanaiste was not necessarily the son of the chief: he might be his brother or nephew; but he should belong to his Fine," or family."

That this mode of election was not always successful we may easily believe. That it was the gradual outcome of the experience of a long series of generations is probable. Where for one cause or another it failed, how would the succession be determined? The most obvious means would be either conflict or divination. According to the legends, divination was sometimes actually used to determine the appointment of king. On one occasion in the days of Conchobar, the famous King of Ulster, the monarchy of Ireland had been vacant for seven years. This state of things being found intolerable, a general assembly was held at Tara to choose a king. The royal houses of Connaught, South Munster, North Munster, and Leinster were there, but the Ulstermen were absent; for there was bitter feud between Ulster and the rest of Ireland, and they would

\footnotetext{
screamel under thy feet. The number of its screams is the number of kings that shall come of thy seed for ever; but I may not name them." In this passage the stone is said to have come from the Island of Foal to abide for ever in the land of Tailtin. Nutt, The Voyage of Bran, vol. i. (1895), p. 187, summarising O'Curry's translation.

' O'Curry, On the Mansers and Customs of the Ancient Irish (three vols., Landon, 1873), vol. i. (Sullivan's Introduction), p. clxxxiii. Spencer, View of the Statc of Ireland, snys that the Tanist is "the eldest of the kinne." Ancient Irish Itissories (Dublin, Ilibemia Press, 1809 ), vol. i., p. 12.
} 
not hold kingly counsel together. The mode of election adopted was divination by means of a dream induced by certain ceremonies. The ceremonies began with a bullfeast. A bull was killed, and a man was gorged with its flesh and broth. We are told "he slept under that meal." It is not incredible. Then "a true oration," which I understand to mean an incantation, was pronounced over him by four Druids. He dreamed, and screamed out of his sleep, and related to the assembled kings that he had seen in his dream "a soft youth, noble, and powerfully made, with two red stripes on his skin around his body, and he standing at the pillow of a man who was lying in a decline at Emain Macha," the royal palace of Ulster. Messengers were accordingly sent thither, and the description was found to correspond with that of Lugaidh Reo-derg, the pupil of Cuchulainn, who was then lying ill. Lugaidh was brought to Tara, recognised as the subject of the vision, and proclaimed as monarch of Ireland.1

This is not the only instance in Irish legend of election to the throne by incubatio, or divination by means of a dream. Conaire, whose tale is filled with incidents explicable only by the comparative studies of ethnologists, was thus elected. Though really begotten by a supernatural bird-man, he was regarded as the son of his predecessor, Eterscéle. But this does not seem to have given him any title to succeed. A bull-feast was accordingly given; and the bull-feaster in his sleep at the end of the night beheld a man stark-naked, passing along the road of Tara with a stone in his sling. Warned and counselled by his birdrelatives, Conaire fulfilled these requirements. He found three kings (doubtless of the under-kings of Ireland) awaiting him, with royal raiment to clothe his nakedness, and a chariot to convey him to Tara. It was a disappoint-

' O'Curry, vol. il., p. 199. From a reference in an Irlsh text translated by Professor Windisch from the LAbor na LVidre, it seems that the bull was required to be while. Irische Texte, ser. I., p. 200. 


\section{The Voice of the Stone of Destiny.}

ment to the folk of Tara to find that their bull-feast and their spell of truth chanted over the feaster had resulted in the selection of a beardless lad. But he convinced them that he was the true successor, and was admitted to the kingship.'

A traditional story is not a record of fact. It is a record only of what is believed. Probably both Lugaidh Reo-derg and Conaire are mythical personages, but their stories certainly embody what was thought to be possible. The description of the election by divination is substantially the same in both. It may therefore be taken, if not as approximately correct, at least as showing that election by divination was regarded among the ancient Irish as in the last resort a reasonable and proper manner of ascertaining and appointing a king. In this the Irish were by no means singular. The traditions of other nations point to the same result, and the customs in various parts of the world confirm it. The incident of election by divination is so picturesque and so suitable for the purposes of a storyteller that it is to be expected far more often in a tale than in real life. But that the story-incident is based on actual practice, I think there is sufficient ground for believing.

We will first shortly review a few stories of election by divination. The Saxons of Transylvania tell of a peasant who had three sons, of whom the youngest was despised by the others because he was weak and small while they were tall and strong. In that kingdom God himself chose the king from time to time. The mode of ascertaining the divine will was'to call a general assembly of the people on the king's meadow in the largest commune of the country, and there to lay the crown at a certain hour on a hillock or mound. All the bells in the town pealed forth together; and the crown slowly raised itself in the air, floated round over the heads of the assembly, and finally alighted on that of the destined

\footnotetext{
'Asume Cellique, vol, xxil,, p. 22, in the story of the Snck of Da Derga's Ilostel, transinted by Whilloy Stokes. X.Jv. 
sovereign. The two elder brothers made ready to attend the ceremony, but bade the youngest remain at home in the ashes, where his place was. However, he slipped out after them, and, for fear they would see him, crept into a pigsty that stood at the end of the town abutting on the meadow. The crown, passing over all the people present, sank down upon the pigsty. Surprised and curious to know what this strange proceeding meant, the people ran to the pigsty, there found the trembling boy, and drawing him forth bowed the knee and saluted him as the new king, called by God to occupy the throne. ${ }^{1}$

In this Transylvanian märchen the crown is the instrument of divination. Going next to the dim and distant East we find other emblems of royalty thus represented. In the Fätaka, the great book of Buddhist Birth-stories, the supposititious child of a merchant's wife of Maghada is the hero of a similar adventure. He is, however, no ordinary child but the Bodhisatta, the future Buddha in an earlier birth. He was called Banyan, from having been found under a banyan tree, where his own mother had forsaken him at his birth. Travelling with two faithful companions who had been born on the same day as himself, he came to Benares, and entering the royal park lay down upon a slab of stone with his two companions beside it. The previous night they had slept in the city under a tree at a temple. One of the youths had awakened at dawn and heard some cocks quarrelling in the branches. He listened, and learnt that whoever killed a certain one of these birds and ate of his fat would become king that very day, he who ate the middle flesh would become commander-in-chief, and he who ate the flesh about the bones would become treasurer. He killed the bird, gave the fat to Banyan, the middle flesh to his other friend, and gnawed the bones himself. Now the king of Benares was dead, and that day the festal car was going

- Ilaltrich, Deutsche Volkswärchen aus dem Sachsenlande in Siebenbürgen, th edition, Vienna, 1885, p. 195. 


\section{The Voice of the Stone of Destiny.}

forth with the five symbols of royalty, the sword, the parasol, the diadem, the slippers, and the fan, within it, to choose the king's successor. As the three youths lay in the royal park, the ceremonial chariot rolled up and stopped before them. The chaplain (presumably a Brahman) followed. Removing the cloth from Banyan's feet he examined the marks upon them. "Why!" he exclaimed, "he is destined to be king of all India, let alone Benares!" and he ordered the gongs and the cymbals to strike up. This awoke Banyan, who sat up. The chaplain fell down before him, saying: "Divine being, the kingdom is thine." "So be it," quietly answered the youth; the chaplain placed him upon the heap of precious jewels and sprinkled him to be king.

In a Calmuck tale the instrument of divination is not one of the royal insignia, but a sacrificial cake. An assembly of the people is held to choose a new khan; and it is decided to appeal to the judgement of heaven by throwing a sacrificial cake, called Baling, apparently a figure of dough, into the air, at the time of the sacrifice (Streuopfer). On whosesoever head the cake fell, he should be khan."

A tale of the Teleut Tartars tells of a father who was enraged with his son because he interpreted the cry of some birds, declaring that they foretold that he himself would become emperor, and his father would drink his urine. The father, in his anger, struck off his son's head. He then killed his horse, skinned it, rolled his son's body in the hide and flung it into the sea. The waves carried the package to a village, where an old woman found it. She opened the leather, and the youth came out alive. The prince of that land had died, leaving no son. His subjects

'The Jalaka, or Stories of the Buddha's former Births, vol. iv., Cambridge, 1901, p. 23. Story No. 445 .

"Jug, Dis Mä́rchen des Siadhi-kïr (Lcipkig, 2866), p. 60, Story No. 2. The version in Miss Busk's Sagas from the Far East is, as usual, not to be depended on. 
took two golden posts, and fastened on their tops two tapers. They then set up the posts in the middle of the village. Every one was required to jump through them, and the tapers would fall on him who was to be the prince. But they obstinately remained standing until the destined youth came, when they both fell on his neck and burst into flame. If he had not become an emperor, at least he was now a prince: and with that variation, the whole of the bird's prophecy was in due course fulfilled. ${ }^{3}$ But we need not follow it further. The hero of a Balochi tale likewise falls under his father's displeasure. His father was a king, and the son took advantage of his royalty to break the crockery of his father's subjects. When the people complained, his father drove him away. In the course of his wanderings, he came to a town where the king had just died. The palace door was shut, and upon it was written: "He whose hand shall open this door, shall be king of this city." The wandering prince, reading this, said: "Bismillah." He pushed the door: it opened. He entered, seated himself on the throne, and became king. ${ }^{2}$

The Kah-gyur, a sacred work of Tibetan Buddhism dating back to the eleventh century or thereabouts, contains a story of king Ananda. The name Ananda is famous in the literature of Buddhism as that of a favourite disciple of the master; but it is here used in the indiscriminate way in which the medirval friars used the names of Pompey, Titus, Pliny, and other famous Romans, in the Gesta Romanorum. This king had five sons, of whom the youngest was endowed with qualities better suited to a ruler than the others, and to whom accordingly he desired to leave the kingdom. But he feared that if he invested his youngest son with sovereign power, his kinsmen would reproach him for having passed over his elder sons. As a way of escape from the difficulty

1 Radloff, Proben dar Volkslitteratur der Türkischen Stimme Sud-Sibiriens (St. Petershurg, 1866), vol. i., p. 208.

- Folk-lore, vol. iv., p. 202. 
he decreed that after his death his sons should be tested, and that he should be made king whom the jewel-shoes should fit, under whom the throne should remain steadfast, and on whose head the diadem should rest unshaken, whom the women should recognise, and who should guess six objects to be divined by insight. ${ }^{l}$ There is a triple test heredivination by the royal insignia, the choice of the harem, and the solution of a riddle. I shall return to the two former tests. But before passing to another type of story I may note that in the Bakhtydr-Nama, a Persian romance translated by Sir William Ouseley, who brought it from the East in the early part of the last century, there is a story in which the succession to the throne is made to depend upon the solution of three riddles. The king having died without issue, it was resolved to go to the prison and propound three questions to the criminals confined there. He who answered best was recognised as king." Riddles are regarded in certain stages of civilisation as a test of more than ordinary wisdom. Their position in the evolution of thought and custom is well worth investigation. It is too large a subject for discussion here.

Occasionally the instrument of divination is wholly wanting, and the first man met with is taken for king. Among a tribe in Morocco is told a tale of which the hero is made king, because he is the first man found outside the city-gate when it is opened in the morning. ${ }^{3}$ Another of these stories is that of Ali Shar and Zumurrud in the Arabian Nights. Ali Shar was a prodigal, and $Z$ umurrud was his favourite female slave. By a series of diverting adventures which do not concern us, they are separated. After much suffering, Zumurrud contrives to possess herself of a man's clothes,

\footnotetext{
'Ralstom Tibelan Tales from Indian Sources (Lundon, 1882), p. 29.

"Sir William Ouseley, The Bakhtydy Nima (edited by W. A. Clouston, 1883), p. 51 .

"Stunme, Märchon der Sihluk zon Tiserwalt (Leiprig, 1895), p. 123, Story No. 15.
} 
horse and sword. In the course of her wanderings she draws nigh to a city-gate, where she finds the emirs and nobles with the troops drawn up and waiting, as Conaire found the three kings waiting on the way to Tara. The soldiery, on seeing her, dash forward. They dismount and prostrate themselves before her, saluting her as lord and sultan. On enquiry she learns that the sultan of the city is dead; and on such occasions it is the custom that the troops sally forth to the suburbs, there to sojourn for three days. Whoever comes during that time from the quarter whence she has come is made king. Being a lady of resource, she accepts the position, administers the kingdom with efficiency, and ultimately finds means to avenge herself on her enemies and to be reunited with her master, Ali Shar.' An Indian folktale relates that in a certain city "it was the custom that when the raja died the nobles of the kingdom used to take their seats at the gate of the city, and the first man who appeared before them they made their raja." "2

The same tale is told by the Taranchi Tartars, an agricultural people who are now settled in the valley of the Ili, a large river flowing into Lake Balkash, in Central Asia. But it is told with this difference. When the hero draws nigh to the gate of the city, all the people cry out "Cuckoo, cuckoo!" On enquiring why they do this, they reply: "Our ruler has been dead for three days. He had a magical bird, which has been let fy, and on whosesoever head the bird settles, him we raise to be our prince." Here the augury is drawn from a bird."

In another Tartar märchen, this time from the west of

' Burton, iv, Arabian Nights, 210, Lane, ii. Arabian Nights (London, 1883), 406.

- North Indian Notes and Queries, vol. iv, p. 66. Similarly in a story from Mirznpur, the first man met in the forest is made king. Jiid., vol. ii., p. $8 \mathrm{t}$. In another slory from Mirzapur a trained elephant is lat loose to choose the king's lride, Jbirl., vol. iii., p. 103 ,

- Radloff, lroben der Folkstitletatur der Norllichen Tibrtischen Strimme, vol. vi. (St. Petershurg, 1886), P. 157. 
Siberia, the ruler of the town has grown old, and is desirous of retiring. He has a bird which is let fly and chooses a woman. She is immediately accepted as prince and installed in the place of the old man. ${ }^{2}$ In a Kurdish märchen a special bird called "the bird of dominion" is fetched, it is not said whence, for the purpose of the divination."

An animal of some kind is, in fact, the agent in most of these tales. A Buddhist tale from Cambodia tells us that, the royal family having become extinct, it was the custom to ask the royal family of another kingdom to furnish a king. The council of mandarins determined to take this course. Under the advice of an old astrologer horses were harnessed to the carriage-we must understand, no doubt, the royal carriage-and then allowed to go in any direction they pleased, without a driver. This is described as consulting the horses. The first day the horses re-entered the palace. The next day they drew the carriage in the direction of a neighbouring kingdom. Twice, thrice the carriage was turned back; but the horses persisted in drawing it again in the same direction. It was accordingly decided to demand a prince from that kingdom.s

In the East, however, as might be expected, it is usually the royal animal, the elephant, which thus confers the kingdom. I have already cited one great collection of Indian tales. There is another, only second to the Fataka in extent, the Katha Sarit Sagara, or Ocean of the Streams of Story, translated a few years ago by Dr. Tawney. It contains a marchen, perhaps derived from that older and more famous collection, the Panchatantra, of a man who retired with his wife to the forest, to practise austerities.

'Boid,, vol. iv. (1872), p. 143.

2Prym und Socin, Kurdische Sammlungen, Erste Abteil. (St. Petersburg, 1887); übersetz., p. 143 .

"Leclère, Caunbodge, Contes et Lejendes (Taria, 1895), p. 16. "Toua ceux qui Graient presents $\mathfrak{a}$ ce conseil . . deciderent qu'on consufteralt immédiate. ment les chevaux." 
While there he rescued from the river a wretch whose hands and feet had been cut off, and who had been thrown by his enemies into the stream to die. His wife, probably sick of austerities, falls in love with the cripple thus rescued, and plots her husband's death. She succeeds in precipitating him into the river; but instead of being drowned he is thrown on the bank near a city. "Now it happened that at that time the king of that city had just died, and in that country there was an immemorial custom, that an auspicious elephant was driven about by the citizens, and any man that he took up with his trunk and placed on his back, was anointed king." The hero of the story, who is " an incarnation of a portion of a Bodhisattva," is of course chosen; and when he gets the chance he inflicts condign punishment on his wife. ${ }^{1}$ The elephant is here described as " an auspicious elephant." Sometimes he is called the "crown-elephant," the special property and symbol of royalty. So in a Tamil story we learn that the king of a certain city dying childless, on his death bed called his ministers together and directed them "to send his crownelephant with a flower-wreath in his trunk, and to choose him on whom the elephant throws the garland, as his successor." " In a folk-tale from the far north of India it is "the sacred elephant" before whom all the inhabitants are required to pass in file, and the animal is expected to elect one of them to the vacant throne "by kneeling down and saluting the favoured individual as he passed by, for in this manner kings were elected in that country." In a story which appears to come from Gujerat, the king dies without an heir, and the astrologers prophesy that his heir would be

1 Kathd Sarit Safrara (Calcutta, 1884), vol. ii., p. 102.

"The Draviritin Nights Entertainments, being a translation of Madana. kAmarijankadai. By l'andit S. M. Natesa Sastri, Madras, 1886, p. 226.

- Wide-Awake Stories. A collection of tales told by little children, between sunset and suntise, in the Payjab and Kitshmir. I3y F. A. Steel and R. C. Temple, Bombay, 1884, p. 140 . In other staries from Kashmir, it is "an elejhant." Knowles, folk-6ales of Kashmir (Lundon, 1888), pp. 169, 309. 


\section{The Voice of the Stone of Destiny.}

the first who entered the gates of the city on the morrow of the king's decease, and around whose neck the sacred elephant would throw a garland of flowers. ${ }^{1}$

At other times the elephant alone does not make the choice. With him is conjoined some other animal or symbol of royalty. A tale from Kashmir speaks of a land where, when the king died, his elephant "was driven all over the country and his hawk was made to fly here, there, and everywhere in search of a successor; and it came to pass that before whomsoever the elephant bowed and on whosesoever hand the hawk alighted, he was supposed to be the divinely chosen one."' In the Kathakofa, a collection of stories illustrating the tenets and practice of Jainism, five ordeals, as they are expressly called, are invoked. "The mighty elephant came into the garden outside the city. There the elephant sprinkled Prince Amaradatta [we have already heard of sprinkling as a means of hallowing to kingship], and put him on its back. Then the horse neighed. The two chowries fanned the prince. An umbrella was held over his head. A divine voice was heard in the air: 'Long live King Amaradatta.'" "s

In most of these cases the decision is clearly regarded as the judgement of Heaven; and in every case the judgement of Heaven may at least be inferred. The incident is hardly less a favourite in the West than in the East. In the West, too, it is an appeal to the judgement of Heaven. All the European stories, however, in which it occurs have been recorded within the last century; consequently the incident in question appears only in a very late form. Now an appeal to the judgement of Heaven in the selection of a ruler is familiar to the peasant mind of the continent in one soli-

'Rerue des Traditions Populaires, vol, iv., p. 442.

"Knowlex, of. cil., p. 158. Other stories, Jbid, pp. 17, 309 , The Bakhtyil. Nima, p. 169 (notes by the Editor), Lal Behuri Day, Fold-taies of Bengal (London, $188_{3}$ ), p. 99, Story No. 5.

"The Nathakopa i or Treasury of Stories. Translated from Sanskrit manu. scripty by C. II. Tawney, M.A. London, 1895, p. 155. 
tary instance-that of the choice of a pope. Accordingly this is the favourite, if not the only form of the story as it is told in France, Italy, and Switzerland. The charming collection by the late $M$. Luzel of religious and quasi-religious tales of Lower Brittany contains one entitled 'Pope Innocent.' The hero is a son of the King of France cast off by his parents, who attempt to put him to death. He sets out for Rome to be present at the election of a new pope. On the way he falls in with two Capuchin monks. The elder of them is gentle to him, the other suspicious and hostile. The youth is a bit of a prig. Perhaps this is not to be wondered at, seeing that he is endowed with supernatural knowledge and power. These qualities make his conduct throughout the journey enigmatical to the point of excusing, if not justifying, the attitude of his unfriendly companion. Everyone takes him for a sorcerer; and the younger monk says in so many words to the other, that they will be lucky if he do not bring them to the gallows or the stake before reaching Rome. As they draw near the holy city, the boy hears some birds in a hedge foretell that one of the three will be made pope, just as the cocks were overheard in the story I cited a few minutes ago from the Fätaka. Thereupon he enquires of each of his companions what office he will give him if he (the monk) attain this dignity. The elder monk promises to make him his first cardinal, the younger contemptuously says he will make him beadle in his cathedral. Arrived at Rome, they find that the choice of a pope proceeds in this way: There are to be three days' processions. Every pilgrim has to carry a candle, not lighted, in his hand; and he whose candle lights of itself is the person designated by God to the office of pope. The youth, however, has no money to buy candles. So he carries merely a white wand which he has cut in the hedge where the birds sang; and people, seeing him, shrug their shoulders and exclaim: "Look at that poor innocent!" It is, however, not the candle of an archbishop, or bishop, or of any great 
dignitary of the church; it is not that of an abbot, or a monk, or even of a simple priest, which lights; it is the boy Innocent's white wand. The omen is refused on the first day; nor is it accepted until it has been repeated on the second and third days of the ceremony. At last the premier cardinal kneels before him, acknowledges him as pope and asks for his benediction. Thus Innocent becomes pope at Rome, by the will of God. ${ }^{3}$

The story of Pope Innocent belongs to the cycle of the Outcast Child, a well-known group of folktales, of which the examples most familiar to us are the story of King Lear and that of Joseph and his brethren. The hero (or heroine) of these tales is cast off by his relatives for reasons at the least excusable. Sometimes, as in the Teleut tale already mentioned, his life is attempted. But in the end he attains a place and dignity which enable him to compel recognition of his wrongs, and, after the infliction of retributive humiliation, to pardon the offenders. In these marchen the pope is not always chosen by the burning of a taper. In the ltalian variants the favourite method is by a dove which alights on the hero's head. In a Swiss story from the Upper Valais two snow-white doves settle on his shoulders. In a Basque story, as the travellers approach Rome the bells begin to ring of themselves. In a story from Upper Brittany the will of Heaven is declared by a bell, which rings of itself when the destined pope passes beneath it. In a story from Normandy the new pope is indicated by "a portion of Heaven stooping upon him whom Jesus would choose to govern his church." The collector, while faithfully recording this singular phrase, is puzzled by it, and suggests that it must mean a cloud resting on him. In all cases it is quite clear that the falling of the lot, however it may be

\footnotetext{
1 Luzel, Lefgendes Chrdicnutes de la Basse Bretaswe, Paris, 1881, vol, i. p. $28_{2}$ (pt. ill., Story No, II); n variant, Mftiwsime, vol. i., col. 300.

Folk-Lore Journal, vol. iv., p. 338, sqq.. including the references at foot of " 348 .
} 
accomplished, is regarded as a direct expression of the divine will. The sacred character of the Papacy, and the names of historical popes, as Innocent and Gregory, given to the heroes, raise the suspicion that these tales are something more than märchen, and lead directly to the enquiry, not whether such prodigies have in fact been the means of determining the succession to the popedom, but whether they have been believed to have occurred.

Now it happens that this very event was reported in connection with the election of the great Pope Innocent III., in the year I 198 . Three doves, it was said, flew about the church during the proceedings, and at last one of them, a white one, came and perched on his right side, which was held to be a favourable omen.' In the atmosphere of the Middle Ages an occurrence of the kind, if it happened, could not fail to make a great impression on the popular mind. The dove would be regarded as no less than the embodiment of the Holy Spirit. Long before Innocent's day-indeed before the Middle $\Lambda$ ges began-something like this would seem to have happened. It is recorded by Eusebius that in the reign of the Emperor Gordian, who ruled from A.D. 238 to 244 , when all the brethren were assembled in the church for the purpose of electing a sucressor to Anteros, Bishop of Rome, suddenly a dove flew down from on high and sat on the head of Fabian. Thereupon the assembly with one voice acclaimed him bishop and seated him on the episcopal throne."

Nor were popes alone thus honoured. Dr. Conyers Middleton, in his once famous Letter from Rome, records that "in the cathedral church of Ravenna I saw, in mosaic work, the pictures of those archbishops of the place who, as all their historians affirm, were chosen for several ages successively by the special designation of the Holy Chost,

- Friedrich von Raumer, Geschichte der Ilohenstanfen und ihrer Zril (leipzig, 1824), vol. iii, p. 74.

"Funelius, Rerrles. Hive, Bonk. vi., c 20. 


\section{The Voice of the Stone of Destiny.}

who in a full assembly of the clergy and people, used to descend visibly on the person elect in the shape of a dove." 1 Among the apocryphal stories in The Book of Sir Fohn Maundeville we are told that in the convent on Mount Sinai are many lamps burning. The author, whoever he may have been, writes rather a muddled account of the election of "prelate of the abbey." I gather from it that each monk has a lamp, and that when a prelate is chosen his lamp will light of itself, if he be a good man and worthy of the office; if otherwise, the lamp, though lighted, will go out. An inconsistent tradition ran that the priest who sang mass for the deceased dignitary found written upon the altar the name of him who was to be chosen in his place. But though the miracle-monger who writes under the name of Sir John Maundeville professes to have been at the monastery and questioned the monks, he admits that he could not induce them to tell him the facts."

The marvels reported of the election of Christian bishops are told with little variation of the election of other rulers. Paulus Diaconus relates that when Liutprand, king of the Lombards, a contemporary of Charles Martel, was thought to be dying, his subjects met outside the walls of his capital, Pavia, at the church of St. Mary ad Perticas, to choose a successor. Their choice fell on the king's nephew, Ilildeprand, in whose hand they formally placed the royal spear. Immediately a cuckoo flew down and settled on the point of the spear, as it will be remembered a cuckoo in the Tartar story settled on the kalender's head. This, however, Was reckoned by Lombard wiseacres as an evil omen. Their augury was so far justified, that King Liutprand did not die after all, but recovered from his sickness and was not well pleased that his subjects had been in such a hurry to find a successor. Yet he did not refuse to recognise his

\footnotetext{
'Mladdeton, Warks (2nd. ed. London, 1755), vol. v, p. 153, citing "Illst.

Raven., \&c. Aring [hus], Rom[a] Subt[erranea], l. vl., c. 48."

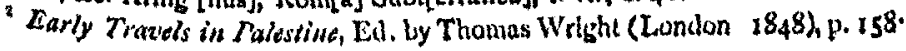


nephew as co-ruler; and when he at last died, Hildeprand succeeded him.l Of another king of the Lombards, Desiderius, a contemporary of Charles the Great, the story is told that the Lombard nobles were meeting to choose a king at Pavia, and Desiderius, a pious man of noble lineage who dwelt at Brescia, journeyed thither to be present, accompanied by a serving man. At Leno, between Brescia and Cremona, being weary, he lay down under a tree to sleep. As he slept his servant beheld a snake crawl forth and wind itself round his head like a crown. The servant was afraid to move, lest the snake might injure his master; but after a while it uncoiled and crept away. Desiderius, meanwhile had dreamt that the crown of the Lombards was placed on his head. When he reached Pavia, the dream was fulfilled."

Every one is familiar with the story told by Herodotus concerning the election of a successor to Smerdis the Magian, usurper of the throne of Persia, how it was agreed that the successful conspirators should meet at sunrise, and that he whose horse first neighed should be king. According to Herodotus, Darius won by a trick of his groom. That may or may not have been. What interests us in the story is that it was believed that the succession on this occasion to the throne of Persia was determined by an augury drawn from horses, and that the neighing of Darius' horse was instantly followed by the further manifestation of the will of Heaven in thunder and lightning from a clear sky. ${ }^{8}$ The elephant, the horse and the divine voice of Indian marchen here find their counterpart, if not in actual fact, at least in the serious belief of the venerable historian, and the people whose tradition he reports. In this connection it

I Paulus Diaconus, Gesta Longrobard., 1. vi., c.55. See also Soldan, Sagen und Geschichicn der Iangobarden (I Talle-a-S., 1888), pj, 145, 148. Hildeprand did not reign long. IIt was deprived of the throne a few months later by Ratchit, who reigned for five years, $744-749$.

"Soldan, of cit., p. 150.

- Ilerodotus, 1. iii, cc. $84,5 / g$. 
must not be forgotten that among many peoples, horses were sacred animals. They were sacrificed to the gods; they were looked upon as in the counsels of the gods: their neighing was a favourable omen. It is therefore not at all improbable that Herodotus is here recording the mode of choice actually adopted. ${ }^{k}$

Similarly in the annals of Keddah, a portion of the Malay Peninsula, there is a story of a rajah who was dethroned and fled. His nobles and queen sent to the King of Siam for a new ruler. He, having consulted his astrologers, was advised that the true heir to the throne could only be discovered by a supernaturally intelligent elephant, named Kamala Jauhari, which was wandering about on the confines of Kedda and Patani. When the envoys brought back the message to the Kedda chiefs, they decked the palace for a fête. "Then all the people held a fast for seven days and nights. .... On the night of the seventh day the dupa and incense were burned, and all sorts of perfumes were diffused around, and at the same time the name of the super-intelligent elephant was invoked toattend upon the four mantris [nobles]. Immediately almost there was a sound, like the rushing of a coming tempest, from the East, with earthquakes, agitations and terrific sounds. In the midst of all this uproar the terrified spectators were delighted to see Kamala Jauhari standing at the hall, and thrusting up her trunk inta it. The four mantris instantly rubbed her with cosmetics and sweet-smelling oils, rubbing these over its whole body. Then a meal was served up to it, and put into its mouth. The state howdah was now placed on its back, along with all its appurtenances, curtains and hanging. Then one of the mantris read the King of Siam's letter close to the ear of Kamala Jauhari, acquainting her that she was expected to assist in finding out a rajah for Kedda by all

'Cirimm has collected instances, Tautonic Mythology, translated by Stally. brass, vol. i., p. 47, vol. ii., p 658, vol. iv., pp. 130r, 1485. Also von Negelein, in Zeilschrift des Vereins filr Volkskunde, vol. x., pp. 408, sqg. 
means. When Jauhari heard all this, she bowed her head and played her trunk, and then set forth in the direction of the East, followed and attended by from three to four hundred men, having banners and flags streaming in the wind, and being supplied with all necessaries, and armed with various kinds of spears, held in hand." It is needless to say that the expedition thus pompously described was successful in discovering the boy. The elephant caught him up in her trunk, and placing him on her back in the howdah, carried him off in triumph to the palace, where he was forthwith clad in royal robes and crowned.

In Indian belief it is not only super-intelligent elephants which can discover the future occupant of a throne. The elephant is the possession and symbol of royalty. But in the stories, other royal properties are also instruments of divination for that purpose. That these stories were founded on current superstitions is shown by the fact that among the ornaments of the throne of the famous Tippoo, conquered by the British at the end of the eighteenth century, was a bird of paradise made of gold and covered with diamonds, rubies, and emeralds, and represented in the act of fluttering. Of this bird it was believed that every head it overshadowed would, in time, wear a crown. When Tippoo was defeated and slain, the Marquis Wellesley, at that time governor-general, sent it home to the Court of Directors of the East India Company. It is now, I believe, at Windsor.

Coming back to Europe, we find the succession to the throne of one of the Scythian tribes determined by the possession of a certain stone. The author of the work on the names of rivers and mountains attributed to Plutarch relates that in the river Tanais a stone like a crystal grows. It resembles in shape a man wearing a crown. When the king dies, whosoever finds it, and can produce it in the

1 Journal of the Sudian Archipalagv, vol. iii., p. $3^{16 .}$

- Oriculal Memoirs, by James Forbes, F.R.S. (London, 1813), vol, iv., p. 191. 
assembly held on the banks of the river to elect a new sovereign, is recognised as the rightful successor. For this statement Ctesiphon on Plants and Aristobulus on Stones are cited, authors whose works are lost and who are unknown by any other citations. It is, therefore, impossible for us to judge how far they are likely to have known, or with what accuracy they may have presented, the practice of the barbarous tribe referred to. There can, however, be no doubt that election by divination has been resorted to by peoples in many parts of the world. The succession of Grand Lamas of Lhasa supplies examples of both story and custom. The custom used to be to write on slips of paper the names of all likely male children born under miraculous portents (of which anon) just after the death of the preceding Lama, to put these slips into a golden urn and thus ballot for his successor (or, as it is believed, his new incarnation) amid constant prayer. But the Chinese court, which has a considerable stake in the decision, was thought to influence the selection. The state-oracle has therefore predicted disaster by the appearance of a monster as the Dalai or Grand Lama, if the ancient practice were continued; and on the last vacancy, in 1876 , he foretold the discovery, by a pious monk, of the present Grand Lama, announcing that his discovery would be accompanied by horse-neighings. He sent this monk to Chukorgye, where he dreamed that he was to look in a certain lake for the future Dalai. There, pictured in the bosom of the lake, the monk saw the child with his parents in the house where he was born, and at the same instant his horse neighed. In due course the child himself was found, and successfully encountered the usual test, by recognising the articles which had belonged to him in his previous life. Every child who is a candidate has to pass this test. He is confronted with a duplicate collection of various sacred objects, and he is required to point out among them the

VOL. XIV.

1 Flutarch, De fivo., xiv. 
genuine possessions of the Dalai Lama. The Dalai Lama is not the only Grand Lama. The head of every lamasery, or convent of lamas, bears this title. When the Grand Lama of such a lamasery dies, his successor, or new incarnation, is sought first of all by divination. A diviner is called in, who, after consulting his books, directs the lamas where to look for the boy. When they have found him, he has to pass a similar test to that just described. In addition he has to submit to cross-examination on the name and situation of the lamasery, and how many lamas reside there, and on the habits of the deceased Grand Lama, and the manner of his death.

The portents at the birth of a Dalai Lama are magnificent. It is not irrelevant to mention them here, as they may be regarded as part of the auguries which decide the succession. An official report from the Chinese Commissioner to the Emperor, on such an occasion in the year 1839 , declares among other things, that it was ascertained that on the night before the boy was born, a brilliant radiance of many colours was manifested in the air, and the water in the well of the temple courtyard changed to a milk-white colour. Seven days later a flame appeared on the rock behind the post-station. When the rock was examined, no trace of fire remained, but a sacred image and characters were found, together with the print of footsteps. Moreover, on the night when the child was born, the sound of music was heard, and milk dropped upon the pillars of the house.'

The Buddhists are not the only sect in the Chinese Empire which has a supreme head appointed by religious divination. The arch-abbot of Taouism dwells in a princely residence on the Dragon and Tiger Mountains, in the province of Kiang-si. "The power of this dignitary," we are

1 Huc, Souvenirs d"un Vograge dans la Tardarie, le Thibet ef la Chine (2 vols., Paris, 1850 ), vol, ii., p. 343 i vol, i., p. 278. The Buddhism of Tibet, by L. Austine Waddell, M.B. (London, 1895), pp. 245. sqg. 
told, "is immense, and is acknowledged by all the priests of his sect throughout the empire." The office has been confined for centuries to one family or clan. When the arch-abbot dies, all the male members of his clan are cited to appear at the official residence. The name of each one is engraved on a separate piece of lead, and deposited in a large earthenware vase filled with water. Standing round this vase are priests who invoke the three persons of the Taouist Trinity to cause the piece of lead bearing the name of the person on whom the choice of the gods has fallen, to come to the surface of the water. ${ }^{1}$

The Taouist dignitary seems to possess only spiritual power, except probably in his own monastery. The Dalai Lama, on the other hand, retains some portion of civil rule. In both cases the person of the ruler is looked upon as sacred. Among savage and barbarous nations the office of priest or medicine-man is often not clearly distinguished from that of temporal ruler. The instances in which the chief or king is looked upon as divine, in which he is responsible for the weather, in which he causes the crops to grow, and performs other superhuman functions, are too numerous, and too well-known to be mentioned here. Since the publication of The Golden Bough they have been among the common-places of folklore. I need only re. mind you that "the divinity that doth hedge a king" is not confined to savagery and barbarism. It has lasted far into civilisation, and been sedulously cultivated for political purposes by royalty in every age. A Roman Emperor was Divus Augustus. When the dignity of king beromes hereditary, the monarch is held to be at least descended from the gods. The Mikado traces his descent from the Sun-goddess. King Edward VIl, traces his from Woden, the war-god of the Anglo-Saxon tribes which colonised Britain in the fifth and sixth centuries. It is true

\footnotetext{
'China, a Ilistory of the Laws, Manners, and Customs of the Seople, by John IJenry Gray, M.A., LL.D. (London, 1878), vol. i., p. I03.
} 
that this genealogy, at one time seriously credited, is now treated as fable, but even yet the coronation ceremonies of 'His Sacred Majesty,' though not directly of pagan origin, witness to the mysterious sanctity that surrounds him.

A view of kingship thus exalted renders it easy to understand why, when circumstances compelled the choice of a king, the divine will must have been most anxiously consulted. It was not merely that the qualities of a leader in battle, a wise judge and administrator, and a prudent politician were needed. Luck and the favour of the gods were more than these, to say nothing of the marks of godhead, which in many cases it was necessary to discover in his person, conduct or knowledge. Hence the choice of the people, or rather the recognition by the people, would depend upon the auguries, or upon more direct indications of the decision of heaven. When Dagara, the King of Karague, on the western shore of Lake Victoria Nyanza, died, he left behind him three sons, any of whom was eligible to the throne. The officers of state put before them a small mystic drum. It was of trifling weight, but being loaded with charms, no one could lift it, save he to whom the ancestral spirits were inclined as the successor. Nor was this enough. The victor in this contest was required to undergo a further trial of his right. He was made to sit, as he himself informed Captain Speke, on the ground at a certain spot where the land would gradually rise up under him, like a telescope, until it reached the skies. The aspirant who was approved by the spirits was then gradually lowered in safety; whereas, if not approved, the elastic hill would suddenly collapse, and he would be dashed to pieces. It is needless to add, that Rumanika, Captain Speke's informant, claimed to have gone through the ordeal with success.'

These are barbarous auguries. But all auguries and ' Journal of the Discovery of the Source of the Nile, by John Ilanning Speke (Edinburgh, 1863), p. 221. 
oracles are barbarous. We do not know how Melchizedek was appointed King of Salem. The writer of the Epistle to theHebrews refers to him as "without father, without mother, without genealogy," as if there were something peculiar in the omission of his pedigree, though in this respect he did not differ from the other kings mentioned in the narrative. However, the discovery at Tel-el-Amarna of letters from Ebed-tob, King of Salem in the fifteenth century B.C., to his suzerain the King of Egypt, has rendered it possible to suppose that Melchizedek did not come to the throne by inheritance, and consequently that his parentage was unimportant. Ebed-tob, protesting his loyalty as an ally and a tributary of the King of Egypt, says: "Neither my father, nor my mother, (but) the oracle of the mighty king, established (me) in the house of (my) father." In other words he states, as Professor Sayce interprets the expression, "that his authority was not based on the right of inheritance; he had been called to exercise it by a divine voice." We must beware of drawing too large an inference from a single phrase. Assuming that "the mighty king" is the god 'Shalim, and not the suzerain whom he is addressing, there remains the question what is meant by "the house of his father." Evidently it is the royal office; but is it not the royal office previously filled by his ancestors? The correct view would seem to be that the kingship was, like that of Karague, descendible to any scion of the royal house, subject to the decision of the oracle. The pedigree then would be important, but not all-important. The god would decide among the candidates. Some such arrangement would seem to have been recognised in the heroic age of Greece, if we may trust the somewhat obscure expressions of the Odyssey. There are examples in the Ilomeric poems of kings who have succeeded to the inheritance of their sires. Agamemnon is one. On the other hand, the position of Ulysses is enigmatical. It is enig-

' keroords of the Past, and series (London, N.D.), vol. v. [1891], pp. 68, 62. 
matical in regard to Laertes, his father, who was still alive; while, if Ulysses were dead, it would seem that Telemachus, his son, would only have the first, but by no means an indefeasible, claim. As Mr. Crooke has pointed out, it results from the interview between Telemachus and the wooers in the first book of the Odyssey, that some kind of divine nomination should appoint the king, and that the choice might fall, not on Telemachus, but on another of the Acheans in sea-girt Ithaca. ${ }^{1}$ It is dangerous to read into the poem what is not expressed. The poet is describing an age already mythical, though no doubt he has embodied considerable fragments of actual custom in the representation. He does not detail the process of appointment of king. Consequently, all we can safely say (and that on the assumption that here we have one of the fragments of actual custom) is that the manners and whole atmosphere of the poem correspond with a stage of culture in which the will of the gods would be ascertained by augury. In this connection it may not be irrelevant to refer to the early traditions of Rome. The quarrel hetween Romulus and Remus concerned not merely the site of the city, but also the founder after whose name it should be called-in other words, the royal dignity. It was settled by an augury taken from the flight of vultures. Numa, the successor of Romulus, though elected, took care to assure himself by auguries that the gods approved of the choice. It must be remembered that the legends, as we have them, took shape: under the republic when the ordinary human process of election had been long established. The habit thus formed probably affected them; and I think we are warranted in suspecting that if we could recover them at a prior stage, we should find the appointment of king resting on the will of the gods and ascertained by divination.

' Folk-Lore, vol. ix., p. 13. Mr. Croske does not refer to the speech of Eurymachus immediately following that of Telemachus, which confirms what has been said on this subject ty Antinous and Telemachuk. 
No argument is needed to show that the form of tradition is affected, even where the substance remains, by external changes. Customs referred to in a legend may become obsolete and consequently unintelligible; and the reference to them must of necessity be modified into something which is understood, or it will be dropped into oblivion. The tradition of the Lia Fail, with which I started, is an example. To step on the stone was to put one's claim to sovereignty to proof. As Kealing relates, doubtless from some older author, on it "were enchantments, for it used to roar under the person who had the best right to obtain the sovereignty of Ireland." But this is the latest form of the tradition. We can, however, reconstruct the earlier form by comparison with custom and tradition elsewhere. They render it clear that the stone was once held to declare the divine will as to the succession. Further back still, it may have been regarded as itself endowed with power of choice. ${ }^{3}$ Strictly speaking, this is not augury, for augury is the ascertainment and declaration of a higher will. But some such animistic belief may have been the seedplot out of which augury grew as gods properly so called were evolved. At the stage at which the tradition reaches us the Lia Fail no longer either chooses on its own account or makes known the choice of heaven. At this stage, not only is it enchanted, consequently diabolic rather than divine in the source of its power, but also it merely points out him who has " the best right." The principle of heredity is now firmly established; its application alone is uncertain. When the principle is established and the application certain, it is not necessary to consult an oracle.

\footnotetext{
'I am indebted to Miss Burne for suggesting that something like this is the true interpretation of the use alike of the Lia fiall and of the various regal paraphernalia employed in the stories. As she puts it, they would know their rightful owner. This, however, is to assume the principle of heredity as already established. The animistic belief involved in the interpretation suggested was perhaps applied even before then.
} 


\section{The Voice of the Stone of Destiny.}

The changes $I$ thus venture to postulate are steps in the disintegration of the myth. A Welsh tale now to be cited has taken a further step in that it simply credits the instrument of divination with the diagnosis of blood royal, the practical purpose of determining the succession to the kingdom having disappeared. According to Giraldus Cambrensis it happened that in the time of Henry l. Gruffydd ap Rhys ap Tudor, who, although he only held of the king one commote, namely, a fourth part of the cantref of Caio, yet was reputed as lord in Deheubarth, was returning from court by way of Llangorse Lake, in Brecknockshire, with Milo, Earl of Hereford and Lord of Brecknock, and Payn FitzJohn, who then held Ewyas, two of the king's secretaries and privy councillors. It was winter, and the lake was covered with water-fowl of various kinds. Seeing them, Milo, partly in joke, said to Gruffydd: "It is an old saying in Wales that if the natural prince of Wales, coming to this lake, command the birds upon it to sing, they will all immediately sing." Gruffydd replied: "Do you, therefore, who now bear sway in this country, command them first." Both Milo and Payn having made the attempt in vain, Gruffydd dismounted from his horse, fell on his knees with his face to the East, and after devout prayers to God, stood up, and making the sign of the cross on his forehead and face, cried aloud: "Almighty and all-knowing God, Lord Jesus Christ, show forth here to-day thy power! If thou hast made me lineally to descend from the natural princes of Wales, I command these birds in thy name to declare it." Forthwith all the birds, according to their kind, beating the water with outstretched wings, began altogether to sing and proclaim it. No wonder that all who were present were amazed and confounded, and that Milo and Payn reported it to the king, who is said to have taken it philosophically enough. "By the death of Christ!" (his customary oath), he replied, "it is not so much to be wondered at. For although by our great power we 
may impose injustice and violence upon those people, yet they are none the less known to have the hereditary right to the country." 1

In the same manner, in India snakes are supposed to be specially gifted with the faculty of distinguishing persons of royal race or born to rule. ${ }^{2}$ One example will be enough. The Gandharbs of Benares, a caste of singers and prostitutes, ascribe their origin to Doman Deo, the second Raghubansi Rajput king of ChandrAvati. He had a groom named Shiru, who one day went into the jungle to cut grass, and fell asleep. While he slept, a cubra raised its hood over his head, and a wagtail kept flying above him. In that condition his master saw him, and afterwards asked him what he would do for him if he became king. Shiru promised to make him his prime mmister. Going subsequently to Delhi, the throne of which was vacant, Shiru was chosen emperor, in the manner with which we are already acquainted, by an elephant laying a garland on his neck; and he redeemed his word by making Doman Deo his wazir." In Further India a saga of the Chams relates that Klong Garay, who plays a great part in their legendary history, was found by a companion of his wanderings, after a temporary absence, sleeping and watched by two dragons, which were licking his body. Then he knew, we are told, that Klong Garay was of royal race. The child of a King of Siam by a Naga, or divine snake, being exposed, was found and adopted by a hunter. The king's subjects were compelled by law to work in turn for the king. The hunter, when summoned, took with him his adopted child and laid it in the shadow of the palace,

\footnotetext{
' Girald. Camlsr, Itinerarium Kambrite, l. i., c. 2.

"W. Crooke, The Popular Religion and' Folklore of Northern India (London, 1896 ), vol, ii., p. 142.

${ }^{3}$ Crooke, The Tribes and Castos of the North-western Provinces and Oudh (Calcutta, 1896), vol. ii., p. 380 . Cf. the Legend of Dhatu Sena, king of Ceylon. Tennent, Ceylon, vol. j., p. 389 (London, 1859).

A. I.anden, Contes Tjamos (Saigon, 1887), p. 104.
} 
to protect it from the rays of the sun while he performed his task. But the spire of the palace inclined before the child, and the shadow appeared to fly. This prodigy put the king upon enquiry, and he identified his son by means of the ring and mantle which he had given to the lady, and which had been found with the child. In the old English metrical romance of Havelok the Dane, the hero is identified by means of a royal mark, "a croiz ful gent," shining brighter than gold on his right shoulder.

\footnotetext{
"It sparkede, and ful brith shon, So doth the gode charbucle ston, That men mouthe se by the lith A peri chesen, so was it brith." "
}

The romance in which the incident is found is a literary version of the local tradition of Grimsby, still commemorated in the seal of the corporation. The poem dates from the end of the thirteenth century. There are two French versions which 1 have not seen. Prof. Skeat has epitomized the longer in the preface to his edition of the English romance. In it a flame issues from Ifavelok's mouth when he sleeps. This is a personal peculiarity, also found in the linglish lay. His heirship to the throne of Denmark is determined by his ability to blow a horn which none but the true heir could sound. Thus we are brought back to the succession by divination from which we started, and of which the simple diagnosis of royal descent is a corruption and a weakening. It is preserved here, we know not by what cause, after its true meaning had been forgotten. Adopted first of all into tradition from living custom, when the custom was superseded by other means of determining the succession it survived as a tradition until, its true intent being gradually lost, while the hereditaty principle was strengthened and fenced about with sanctity, the incident faded into a merely picturesque pre-

1 Journal of the Itedian Arrhipelago, vol. iii., p. 57 r.

- The Lay of Havelok the Dane (E. E. T. S.), 11. 602, sgg. $12139 . \mathrm{sgq}$. 
sentation, in some places of prophecy, in other places of the claims of birth.

The study of folktales is often despised as mere triffing. But traditional narratives must always occupy an important place in the study of the past. Rightly used they have much to tell us of human history, of human thought and the evolution of human institutions. It may safely be said that of all the incidents that compose them there is none which is not a concrete presentation either of human institutions or of human belief. They are all thus in a sense the outcome of actual human experiences. The stories of election by augury are not wilder than the authentic facts. The telescopic mountain of Karague, which Rumanika averred himself to have experienced, is at least as wonderful as the groaning of the Lia Fail, or the lighting of a dry twig. In one of the stories we found the dying monarch laying down among the conditions to be fultilled by his successor, that the women of the royal household should recognise him. Secret intrigues of the harem are believed to determine the devolution of many an eastern crown. But that the formal and ceremonial choice of the heir should be made by the wives of the deceased ruler seems too grotesque to be known outside a fairy tale. Yet this was the law a hundred years ago in the kingdom of Quiteve, on the south-eastern coast of Africa. When a king died the queens (that is to say, his legitimate wives) named the person who was to accompany his body to the burial-place, and the person thus named became the successor. ${ }^{2}$ In an adjoining kingdom a similar law prevailed. It was forbilden to any prince to enter the palace where the women were, or to take possession of the kingdom without their consent, and whoever entered by violence and took posses-

1 Owen, Narrative of Voyages to explove the shores of Africa, Arabia and Arudagascar $(2$ vols. London, 1833), vol, ii, p. 418, translating a MS., of Signor Ferán, a Portuguese governor of the coast. This translation is reprinted hy Theal, Recoros of South-eastarn Afriea, vol. vii., pp. 371, spg. 
sion against their will, lost his right of succession. The Portuguese friar, to whom we are indebted for the information, records a case which happened while he was in Sofala, and in which the claimant entered and formally seated himself in the royal hall with the royal widows. They, however, were unwilling to acknowledge him as their king and husband. Accordingly they secretly summoned another member of the royal family, seated him with them in the public place, and sent officers through the town to proclaim the new sovereign and call his subjects to do homage. The pretender fled. This instance is the more remarkable because the unsuccessful claimant had in his favour the nomination of the previous monarch. Though this constituted not an indefeasible title, it afforded at least a strong presumption in his favour. Yet it was defeated, in accordance with established and publicly acknowledged custom, by the choice of the harem. ${ }^{1}$

I Theal, kecords, vol, vii., pp. 191, syg. 
Pl.ATE I.

FETISH DOLL

(Achewa Tribe, Central Angoniland)

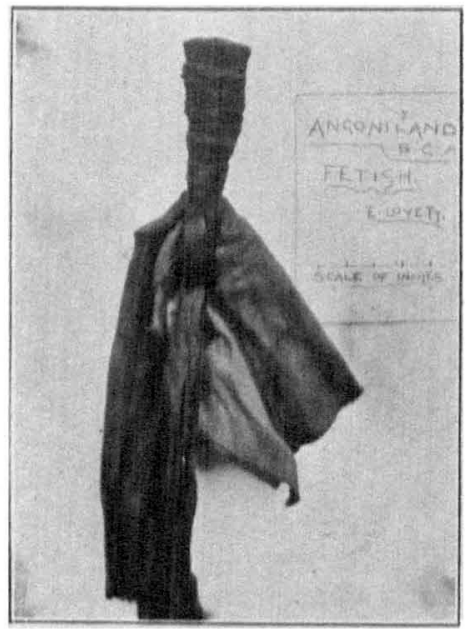

Into which the Spirit of a Deceased Ancestor has heen CONJURED.

To face page 61. 